\title{
BOURDIEU, UM OLHAR MARXISTA
}

\author{
BURAWOY, Michael. \\ O Marxismo encontra Bourdieu \\ Campinas: Editora da Unicamp, 2010, 183 p.
}

POR

\section{Leda Maria de Oliveira Rodrigues ${ }^{1}$}

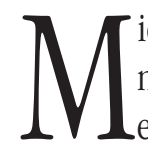

ichel Burawoy reavalia a teoria de Bourdieu quando esta já é reconhecida mundialmente. Para isso, revisita autores de seu conhecimento estabelecendo um diálogo entre eles e de cada um deles com Bourdieu. A teoria marxista é o parâmetro de comparação, pois os autores revisitados se consideram marxistas: Karl Marx, Antonio Gramsci, Frantz Fanon, Simone de Beauvoir e Wright Mills. Além disso, o autor discute as bases de suas próprias pesquisas, comparadas com Bourdieu e com a teoria marxista.

A análise de Burawoy, a meu ver, tem um fio condutor que perpassa todos os autores, caracterizado por dois pontos: a preocupação de Bourdieu de isolar a sociologia do mundo social, defendendo a autonomia da universidade — uma ciência para os cientistas - e o desvendar da exploração das classes dominadas, chave da transformação social capitalista.

Retomando Marx e Engels, Burawoy destaca as convergências e divergências entre eles e Bourdieu. Sinteticamente podemos dizer que o autor teve o mérito de mostrar como Bourdieu completou a obra de Marx, ou seja, o estudo das superestruturas sociais, com uma análise mais estrutural e funcional e não somente histórica.

No diálogo entre Bourdieu e Gramsci o autor esclarece que as convergências são muitas: ambos repudiaram o determinismo histórico de Marx; desenvolveram concepções sofisticadas sobre as lutas de classe; focaram o mesmo aspecto social

\footnotetext{
${ }^{1}$ Professora do Programa de Estudos Pós-Graduados em Educação: História, Política, Sociedade; da Pontifícia Universidade Católica de São Paulo,Brasil. ledamor@uol.com.br
} 
- que Gramsci chamou de superestruturas do capitalismo, e Bourdieu de campos de dominação simbólica. Tanto um como outro deram pouca importância à economia e centraram suas análises nos efeitos dela. Ambos se interessaram pelas questões de dominação e reprodução da dominação. Procuraram também definir o papel dos intelectuais na política, ou seja, o lugar que ocupam na reprodução e na transformação da ordem social.

Burawoy desvenda uma diferença importante entre o conceito de violência simbólica de Bourdieu e o conceito de hegemonia de Gramsci. Violência simbólica para Bourdieu significa desconhecimento da dominação como tal, para Gramsci hegemonia implica o consentimento consciente à dominação. Gramsci admite 0 bom senso dentro do senso comum da classe operária, enquanto que para Bourdieu o senso comum era sempre o mau senso, no mau sentido. Assim, os dominados jamais entenderiam as causas da dominação. Somente os intelectuais teriam a chave dos segredos da sociedade e da dominação sobre a qual ela se assenta; já os indivíduos dominados estariam cegos e surdos por sua submissão. Aqui Bourdieu sinaliza certo desprezo pelo conceito de intelectual orgânico de Gramsci.

No capítulo seguinte, Burawoy, por meio de suas pesquisas etnográficas, procura compreender se é possível e, nesse caso, como ocorre a fabricação do consentimento da exploração, tentando assim verificar a tese de Gramsci (consciência da dominação) e de Bourdieu (desconhecimento da dominação).

A partir da observação das relações de trabalho realizada em regimes despóticos de fábrica, o autor demonstra que aí a exploração a partir da dominação é facilmente desenvolvida. Neste regime de trabalho, as regras do jogo são tão arbitrárias que impossibilitam o consentimento da dominação pela exploração. De outro lado, ambientes hegemônicos de trabalho são mais favoráveis ao consentimento da exploração, as certezas e as incertezas são fruto de um ambiente de trabalho relativamente autônomo, encobrindo a verdade objetiva do trabalho: a exploração.

0 autor discorre ainda sobre a teoria bourdiesiana, especialmente sobre os conceitos de dominação simbólica e babitus. Para ele, estes conceitos não dão conta de analisar as condições da exploração do trabalhador no capitalismo. 0 primeiro, por desconsiderar as condições institucionais da exploração e o segundo, por considerar que as disposições, embora herdadas de um contexto anterior pela situação seguinte, não são tão determinantes como Bourdieu afirmava. Segundo 0 autor, as disposições (habitus) são colocadas num segundo plano devido a repetitivas e incessantes relações sociais, nas quais dominantes e dominados estão juntos. No momento em que a coesão entre as relações sociais se perde, o babitus 
assume o controle. Assim, o babitus pode desempenhar papel coadjuvante na reprodução da dominação, mas pode desempenhar papel principal na criação de novas ordens sociais.

As observações realizadas apontam a tendência de submissão maior nas instituições de capitalismo avançado e de uma subversão nas instituições de socialismo estatal. Enquanto o capitalismo avançado organizava a mistificação simultânea da exploração e do consentimento à dominação, o socialismo buscava apresentar os interesses do estado como sendo interesses de todos. No entanto, percebia-se essa intenção como algo frágil e sempre ameaçado pela escandalosa transparência da exploração.

A comparação seguinte é entre Bourdieu e Frantz Fanon. Confronta aqui a idéia de colonialismo e revolução, a partir das experiências de Bourdieu e Fanon na Argélia, durante os conflitos pela libertação nacional. Bourdieu se insere na Argélia para desenvolver pesquisas sociológicas buscando resgatar a dignidade e aprofundando a verdade sobre a vida do colonizado. Fanon entra em contato diretamente com as vítimas da violência em ambos os lados das classes envolvidas no colonialismo. Ambos convergiram para a sociologia, mas ao mesmo tempo com certo interesse na psicologia como apoio da pesquisa sociológica. Esse interesse se expressa, segundo Burawoy, "tanto na nebulosa noção de babitus em Bourdieu como na influência da psiquiatria lacaniana em Fanon". (p. 110)

Ao longo desse capítulo Burawoy desenvolve as formas como Fanon e Bourdieu analisam as possibilidades de libertação da Argélia do regime colonial. Apesar de suas diferenças, ambas as críticas ao colonialismo se aproximavam mantendo avaliações e explicações bastante próximas quanto à ordem colonial. Bourdieu via o fim do colonialismo a partir da transição da sociedade tradicional para a modernidade, enquanto Fanon enxergava a transformação colonial por meio do marxismo, como transição do capitalismo para o sistema socialista. Bourdieu entendia que essa transição em busca da modernidade envolvia a orientação rumo ao futuro, sendo este planificado racionalmente e dependente da classe trabalhadora urbana. 0 campesinato vislumbrava, no máximo, um futuro utópico da negação mágica e imediata do presente. Aqui, vemos a postura de Bourdieu voltada para um marxismo ortodoxo, segundo o qual a classe trabalhadora argelina seria naturalmente revolucionária por estar enraizada em um emprego estável. Por outro lado, ao campesinato desenraizado caberia, quando muito, uma rebelião espontânea e inconsciente. Esta é a principal discordância entre Fanon e Bourdieu, ou seja, em quais condições o colonialismo teria seu fim. Fanon acreditava na revolução a partir dos camponeses, classe revolucionária por 
excelência, mesmo princípio da Frente de Libertação Nacional.

No penúltimo capítulo, Burawoy faz uma discussão entre Bourdieu e Simone de Beauvoir a partir de duas de suas publicações de extrema importância, a saber: A dominação masculina e $O$ segundo sexo, respectivamente. Burawoy aponta como Bourdieu praticamente desconsidera o trabalho de Beauvoir, partindo de seu conceito de violência simbólica. Segundo Bourdieu, isto ocorreu em função da relação estabelecida entre ela e Jean-Paul Sartre, a quem teria delegado sua capacidade de produzir filosofia. Aponta esse aspecto como exemplo de violência simbólica, na constituição de uma relação patriarcal entre os sexos. Em função dessa violência, a autora não teria aplicado a análise que fez das relações entre homem e mulher na análise da relação estabelecida entre ela e Sartre. Em outras palavras, teria sofrido a dominação masculina a ponto de não desenvolver uma filosofia própria.

Burawoy aponta que dessa interpretação de Bourdieu sobre os trabalhos de Beauvoir pode ter decorrido o fato dele não citá-la em seu livro A dominação masculina, texto com muitas referências às inúmeras correntes do feminismo.

Bourdieu pode ser duplamente condenável, por não reconhecer que Beauvoir antecipou o feminismo da próxima geração e por não reconhecer que utilizou muito de suas idéias em $A$ dominação masculina - o livro de Bourdieu foi escrito 50 anos depois de $O$ segundo sexo.

Finalmente, Burawoy mostra como Bourdieu foi influenciado por Wright Mills e em que sentido ele pode ser considerado como "um Bourdieu estadunidense", não obstante tenham vivido em épocas muito distantes. Dentre as convergências entre eles, Burawoy levanta a relação de ambigüidade que mantiveram com o marxismo. Eram contrários à figura do intelectual orgânico e desenvolveram seus trabalhos afastados do contato direto com o povo, defendendo a idéia do intelectual tradicional. Outra convergência importante se refere ao fato de que ambos os autores utilizaram em seus programas de pesquisa as mesmas categorias de estratificação social: classe trabalhadora, classes médias e as elites.

Ao contrário de Bourdieu e Mills, que excluem os intelectuais da sociedade considerando os intelectuais tradicionais isolados dos orgânicos, há também abordagens contemporâneas, como é o caso de Burawoy, que defendem a importância da interdependência entre eles.

Iniciantes e conhecedores do trabalho de Bourdieu devem ler o livro de Burawoy, pois este examina a obra de Bourdieu de forma clara e cuidadosa. Como sociólogo marxista não dogmático elabora críticas sem deixar de reconhecer a importância do marxismo na atualidade. 